\title{
Постановка методики анализа содержания алкалоидов в тканях некоторых видов семейства пасленовых методом высокоэффективной жидкостной хроматографии
}

\author{
Д.В. Домрачев ${ }^{1 *}$, А.А. Егорова ${ }^{2}$, К.А. Колошина ${ }^{2}$, С.В. Герасимова ${ }^{2}$ \\ ${ }^{1}$ Новосибирский институт органической химии имени Н.Н. Ворожиова СО РАН, \\ Новосибирск, Россия \\ ${ }^{2}$ ФИЦ Институт ичитологии и генетики СО РАН, Новосибирск, Россия \\ *e-mail:dmitry@nioch.nsc.ru
}

Одной из важнейших характеристик хозяйственных растений является содержание вторичных метаболитов, в том числе и такого важного класса соединений, как алкалоиды. Для картофеля (Solanum tuberosum) важно контролировать содержание гликоалкалкалоидов соланина и хаконина. Для табака (Nicotiana tabacum) важнейшим хозяйственным признаком является содержание никотина и минорных алкалоидов анабазина и анатабина. Наиболее универсальными методами анализа содержания алкалоидов в растительном сырье являются высокоэффективная жидкостная хроматография (ВЭЖХ) и газожидкостная хроматография (ГЖХ).

Целью данной работы являлась постановка и отработка методики анализа содержания соланина и хаконина в различных тканях картофеля и никотина в листьях табака методом ВЭЖХ. Для этого проводили оптимизацию условий пробоотбора и пробоподготовки, а также оптимизацию условий проведения хроматографического анализа.

Соланин и хаконин извлекаются из тканей картофеля экстракцией $5 \%$ водным раствором $\mathrm{CH}_{3} \mathrm{COOH}$. Сумма гликоалкалоидов осаждается $\mathrm{NH}_{4} \mathrm{OH}$, реэкстрагируется и повторно осаждается. Из надземной части картофеля сорта «Златка» был получен образец суммы алкалоидов в кристаллическом состоянии, используемый в дальнейшем в качестве стандарта. Суммарное содержание гликоалкалоидов в надземной части составило 0,17\%. Анализ проводился на обращенно-фазной колонке ZORBAX-SB-C18, элюент 0,1\% $\mathrm{CF}_{3} \mathrm{COOH}$, детектирование - на длине волны 205 нм. Использование данного метода для анализа клубней и ростков не дает удовлетворительных результатов, проводится дальнейшая оптимизация условий пробоподготовки.

Для анализа содержания никотина использовались листья взрослых растений табака сорта SR1. Материал брался от интактных растений и после удаления верхушечных и пазушных меристем. Извлечение никотина проводилось экстракцией $40 \%$ метанолом с $0,1 \mathrm{M} \mathrm{HCl}$ в течение суток с дальнейшим центрифугованием. Суперагент сводился в колонку. Анализ проводился на обращенно-фазной колонке ZORBAX-SB-C18 в системе 0,1 \% $\mathrm{CF}_{3} \mathrm{COOH}-\mathrm{CH}_{3} \mathrm{CN}$ (9:1), детектирование на длине волны 260 нм. Использование метода добавок стандарта показало практически полное извлечение никотина из растительных тканей. Получена калибровка для количественного содержания никотина. Определено содержание никотина в различных образцах. После удаления верхушечных и пазушных меристем содержание никотина увеличилось в 1,5-2 раза.

Благодарности: Работа выполнена при финансовой поддержке грантов РФФИ № 18-316-00068 и 18-416-543004. 